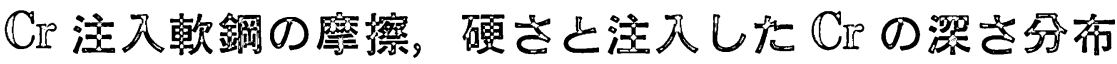

\author{
岩木 正哉, 吉田 清太 \\ 理化学研究所 $\mathbf{T} 351$ 埼玉県和光市広沢 $2-1$ \\ (1981 年 6 月 5 日受理)
}

\section{Friction, Hardness and Depth Profiles of Chromium Implanted Mild Steel}

Masaya Iwaki and Kiyota Yoshida

The Institute of Physical and Chemical Research, Hirosawa 2-1, Wako, Saitama, 351

(Received June 5, 1981)

\begin{abstract}
A study has been made of the friction and hardness of chromium implanted mild steel. Ion implantation was performed with doses of $1 \times 10^{15} \sim 1 \times 10^{17} \mathrm{ions} / \mathrm{cm}^{2}$ at $50 \sim 150 \mathrm{keV}$. energies The friction coefficients and the Vickers hardness of $\mathrm{Cr}$-implanted specimens were measured with a Bowden-Leben type friction testing machine and a micro-Vickers hardness tester, respectively. All tests were carried out at atmospheric room temperature. The friction coefficients had a tendency to decrease as the $\mathrm{Cr}$ fluence increased, but were independent of the acceleration energy. As the dose increased. the Vickers hardness increased at a lower normal load than $10 \mathrm{gf}$, Concentration profiles of $\mathrm{Cr}$ were measured by secondary ion mass analysis in order to investigate the surface layer depth which contributes to friction and hardness properties. The $\mathrm{Cr}$ profiles showed abnormally high concentrations of oxidized chromium down to $200 \AA$ from the surface, not predicted by the range theory, and which are supposed to cause a decrease in the friction coefficients and an increase in the hardness.
\end{abstract}

\section{1. はじめに}

加速したイオンを固体材料の表面層に添加して表面層 の特性を変えるイオン注入法は, 半導体素子作成におけ る不純物ドーピング技術として, シリコンにおいてはす でに確立されてきている1”。乙の方法を金属材料の表面 層改質に使用するという試みは，すでに 1970 年代初頭 から行われていた ${ }^{2,3)}$ 。

金属へのイオン注入に関する研究は，注入材の物理的 性質をはじめとして, 機械的性質, 化学的性質における 基礎的研究から応用的研究にいたるまで広範围にわたっ て行われている4)。なかでも 鉄鋼への窒素イオンの注入 に関しては，工具鋼に応用され，耐摩耗性における実用 試験においては良好な結果が得られている5)。乙れは鉄 の窒化層が形成された結果であると考えられている。し かし, 酸性の酢酸系溶液中での電気化学的性質において
は未注入試料とほぼ同様な性質がみられ，窒素注入に よって電気化学的特性の大きな変化は認められなかっ た6”。また，高温酸化においてむ良好な結果は得られて いないようである5 。

一方，代表的合金であるステンレスと注入鉄との比 較をする上で重要な $\mathrm{Cr}$ のイオン注入については, Ashworth らによって古くから調べられている。彼ら は, 酢酸系中性溶液中におりる電気化学的性質を調べ, $\mathrm{Cr}$ 注入鉄は不活性化するととを示した ${ }^{7)}$ 。また, McCafferty らはべアリングへ Cr をイオン注入し， Cl を 含む油を用いて耐食性試験を行っている8 $\mathrm{Cr}$ 注入鉄の電気化学的性質について報告してきた ${ }^{9,10)}$ 。 その結果, $150 \mathrm{keV}, 1 \times 10^{17} \mathrm{Cr} / \mathrm{cm}^{2}$ 注入した鉄は $\mathrm{Fe}-$ $18 \% \mathrm{Cr}$ と同様な性質を示した。しかし， Cr 注入鉄の摩 擦現象や硬さについての報告はみあたらない。

ここでは，軟鋼へ $\mathrm{Cr}$ を種々の注入条件でイオン注入 
し, ビッカース硬さや摩擦係数の変化量の测定結果につ いて述べる。さらに，これらの結果と $\mathrm{Ni}, \mathrm{Cu}$ を注入し た場合 ${ }^{11)}$ 比較して Cr のイオン注入効果について検討 する。また二次イオン䢙量分析法で測定した注入イオン 分布とこれらの性質の関係について述べる。

\section{2. 実験方法}

\section{1 試料作 成}

イオン注入に使用した試料は市販の軟鋼 (SPCC) であ る。この試料の不純物については参考文献 12) を参照さ れたい。注入前に試料をシリコンカーバイド, $2 \mu$ アル ミナを用いたバフ研磨で仕上げ, トリクレン中で超音波 洗浄した。

イオン注入は理研 $200 \mathrm{kV}$ 注入装置を用いた ${ }^{13)}$ 。注入 条件は加速電圧 $50,100,150 \mathrm{kV}$, 注入量 $1 \times 10^{15} \sim 1 \times$ $10^{17} / \mathrm{cm}^{2}$, イオン電流密度 $1 \sim 2 \mu \mathrm{A} / \mathrm{cm}^{2}$ であった。注入 中の基板温度はイオンビーム自身により室温から数百度 に上昇した。注入中の真空度は約 $1 \times 10^{-6}$ Torr であっ た。なお，摩擦係数の测定における関係からすなわ ち, 注入面と末注入面を区別するために試験片の半分を アルミ箔でマスクして注入している。

\section{2 摩擦係数の測定}

摩擦係数の測定には，Fig. 1 亿示すような BowdenLeben 型の摩擦試験機を用いた。注入材の相手材は, 注 入材よりも強い炭素鋼 (S 45 C) 棒で, その先端は半径 $2 \mathrm{~mm}$ の半球に仕上げたあのである。使用した荷重は主 に 60, 120, $180 \mathrm{gf}$ であり，すべり速度は $2.7 \mathrm{~mm} / \mathrm{s}$ で 一定とした。摩擦力は棒を支える板バネの変位を歪みゲ ージにより測定した。イオン注入による摩擦係数への明 確な変化を得るために, 棒と試料の接触部分を未注入領 域から注入領域へ向って連続的に滑らせた。なお, 以上 の摩擦試験は大気中, 室温, 無潤滑下で行った。

\section{3 硬さの測定}

ビッカース硬さの測定にはデジタル計測顕微鏡（赤

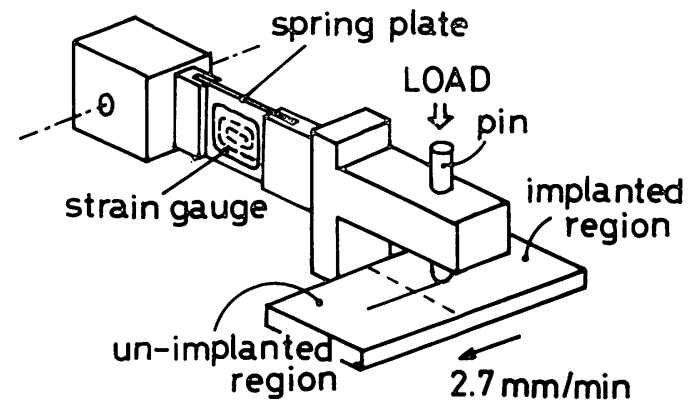

Fig. 1 Bowden-Leben type friction testing machine.
石製作所 DME) 付極軽荷 重微小硬度計（赤石製作所 MVK-1）を用いた。測定に使用した荷重は 1.5，3，6， 11，21 gf であり，加重速度は $0.034 \mathrm{~mm} / \mathrm{s}$ であった。 荷重をかけた時間は 15 秒である。なお，硬さへのイオ ン注入効果を明らかにするために，硬さの測定はできる だけ近い注入領域，未注入領域で行った。

\section{4 注入イオン分布の測定}

分布測定には二次イオン質量分析装置 (Commonwealth Scientific 社製, ISMA) を用いた ${ }^{14)}$ 。加速電圧 は約 $7 \mathrm{kV}$ であり,ビーム電流は $30 \mu \mathrm{A}$ である。注入 イオン分布における濃度は, 測定した母材元素の鉄 $\left(\mathrm{M}_{\mathrm{F}}\right)$ と注入したイオン種 (MI）の二次イオンの相対電流比 $\left(\mathrm{M}_{\mathrm{I}}{ }^{+} / \mathrm{MF}^{+}\right)$にっって表示した。また，深さは最終深さを 荒さ計，または，干涉顕微鏡で測定し，スパッタ時間の 配分によって各深さを決定した。通常のスパッタ率は 20〜30 $\AA / \mathrm{min}$ であった。

\section{3. 実験結果}

\section{1 摩擦特性}

Fig. 2 亿荷重 120 gf で未注入領域から Cr 注入 $(1 \times$ $\left.10^{16} \mathrm{Cr} / \mathrm{cm}^{2}, 100 \mathrm{keV}\right)$ 領域にかけて滑らせた時の摩擦 トレースの例を示す。縦軸は摩擦力で横軸は滑らせた時 間でほぼ滑り距離に対応している。試料の摩擦トラック は肉眼でみえるキズを発生しているが，摩擦トレースは Cr 注入によって摩擦力は減少し, また, Stick-slip 効果 あわずかに減少するととを示している。乙の試料におけ る摩擦力之荷重とは $60 \sim 180 \mathrm{gf}$ の荷重範团で直線関係 にあり，乙の傾きが摩擦係数 $(\mu)$ である。得られた未注 入属の摩擦係数 $\left(\mu_{u}\right)$ は 0.56 であり, $\mathrm{Cr}$ 注入属の摩擦 係数 $\left(\mu_{I}\right)$ は 0.46 である。

末注入金属の $\mu_{u}$ が試料によって 0.5 から 0.6 亿変動 するため, 摩擦係数の相対変化量 $(\Delta \mu)$ を次のように定 義した。

$$
\Delta \mu=\left(\mu_{I}-\mu_{u}\right) / \mu_{u}
$$

種々の注入量, 加速電圧で注入した試料の $\Delta \mu$ を Fig. 3 に示す。 $\mathrm{Cr}$ 注入材における $\Delta \mu$ は $\mathrm{Cr}$ の注入量の増加 とともに減少するが，加速電圧による影響はあまり明ら かではない。

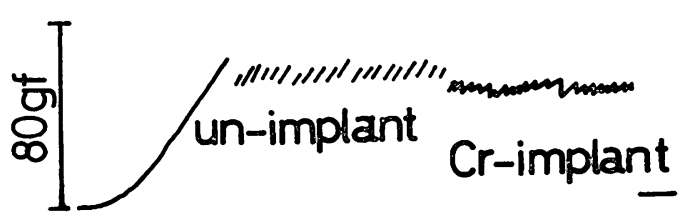

Fig. 2 Friction trace for specimens with $1 \times 10^{16} \mathrm{Cr} / \mathrm{cm}^{2}$ at $100 \mathrm{keV}$. The applied load is $120 \mathrm{gf}$. 


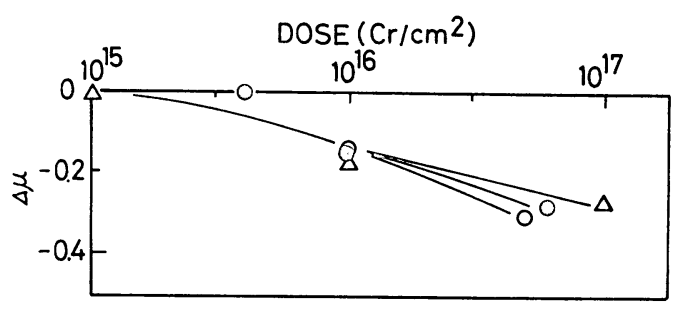

Fig. 3 Relative change in friction $(\Delta \mu)$ as a function of dose in the case of $\mathrm{Cr}$ implantation. Acceleration energies were 50(O), $100(\odot)$ and $150 \mathrm{keV}(\triangle)$.

\section{2 硬 さ}

Fig. 4 に $150 \mathrm{keV}$ 種々の注入量で $\mathrm{Cr}$ をイオン注入 した軟鋼の硬さに関する荷重依存性を示す。未注入材に おいても高荷重のときよりも低荷重側で硬くなってい る。乙の表面硬化の原因は，表面の加工層の効果による あのであると考えられる。なお， $1 \mathrm{kgf}$ でのビッカース 硬さは $110 \mathrm{~kg} / \mathrm{mm}^{2}$ 以下であった。

末注入材と注入材の硬さの違いは低荷重側で明瞭であ り, $11 \mathrm{gf}$ 以上の荷重では認められない。荷重約 $10 \mathrm{gf}$ でビッカース硬さ 180 程度のとき圧痕の深さは約 1.5 $\mu \mathrm{m}$ であり，乙れは注入属の 10 倍の深さに対応する。 荷重 $1.5 \mathrm{gf}$ の時には Cr 注入材は未注入材に比べ $50 \%$ 以上硬くなっている。乙のときの圧痕の深さは約 0.3 $\mu \mathrm{m}$ であり，乙れは注入属の 3 倍程度である。乙のた め, 実際の表面硬さはさらに大きくなっていると考えら

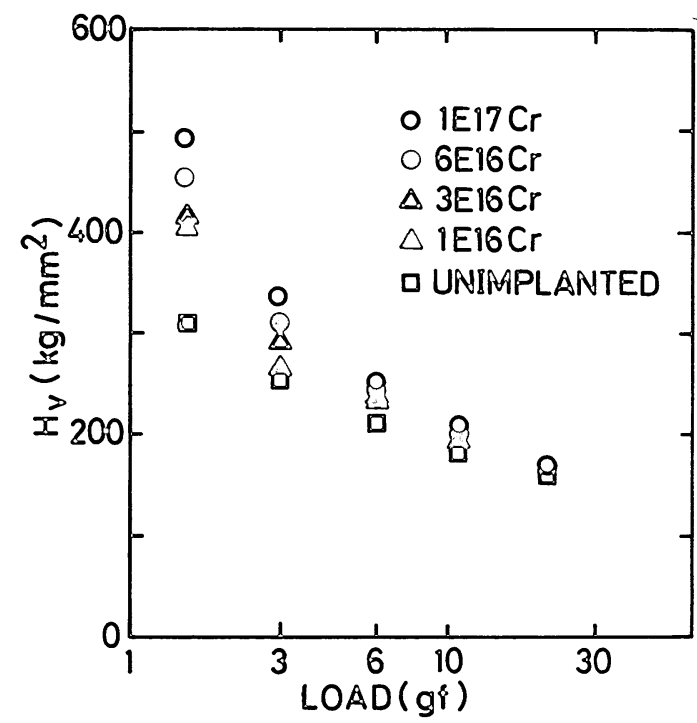

Fig. 4 Vickers hardness as a function of normal load on $\mathrm{Cr}$ implanted and un-implanted regions. Ion implantation was made with $10^{16}(1 \mathrm{E} 16) \sim 10^{17} / \mathrm{cm}^{2}(1 \mathrm{E} 17)$ at $150 \mathrm{keV}$.

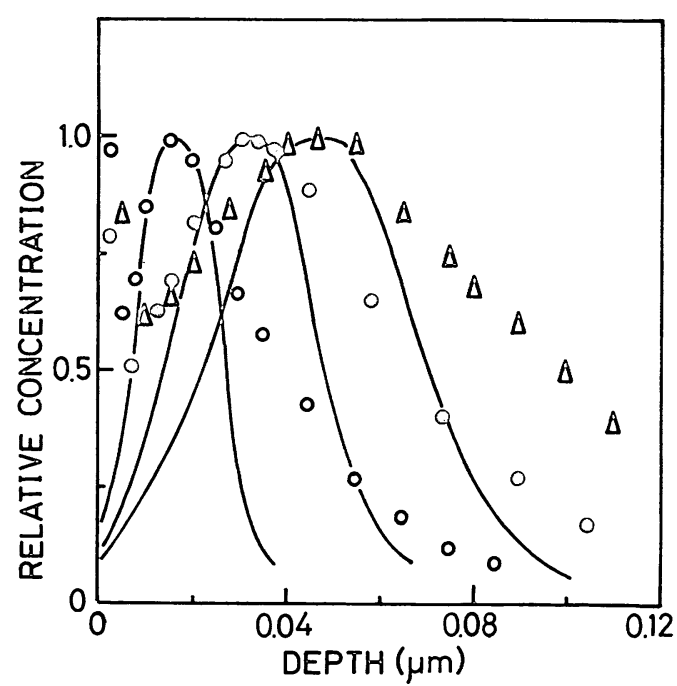

Fig. 5 Concentration profiles of $\mathrm{Cr}$ implanted in iron with $5 \times 10^{15} / \mathrm{cm}^{2}$ at $50 \mathrm{keV}(\mathrm{O})$, with $10^{16} / \mathrm{cm}^{2}$ at $100 \mathrm{keV}(\odot)$ and with $1.5 \times 10^{16}$ $/ \mathrm{cm}^{2}$ at $150 \mathrm{keV}(\triangle)$.

れる。乙の硬さの増加傾向は注入量の増加とともに大き くなっている。この硬さの増加傾向は摩擦係数の減少之 対応している。

\section{3 注入した $\mathrm{Cr}$ の分布}

Fig. 5 に軟鋼へイオン注入した $\mathrm{Cr}$ の深さ濃度分布 を示す。注入条件は $50 \mathrm{keV}$ で $5 \times 10^{15} / \mathrm{cm}^{2}, 100 \mathrm{keV}$ で $1 \times 10^{16} / \mathrm{cm}^{2}, 150 \mathrm{keV}$ で $1.5 \times 10^{16} / \mathrm{cm}^{2}$ である。これら の条件における各加速電圧における各注入量の選択は, 注入中のスパッタリング効果が無視でき, また, 最大濃 度がほぼ等しくなるように行った。濃度は母材の鉄の二 次イオン電流に対する $\mathrm{Cr}$ の電流比として求め, 最大濃 度を 1 として相対的に表示した。図中の実線は飛程理論 から計算される分布を示す15)。

Cr の分布の特色は二つのピークをむつととである。 第一のピークは表面近傍にあり，乙のピークは飛程理論 では予測されないものである。また, 濃化の度合は加速 エネルギーの明瞭な依存性がみられない。との表面濃化 属にある Cr は光電子分光法で状態分析した結果, 酸化 した状態であることがわかった。第二のピークは飛程理 論で予測される深さにある。

第二のピークより深い領域において Cr は飛程理論で 予測されるよりあ深くまで侵入している。このような深 い侵入は鉄へイオン注入した $\mathrm{Ni}$ や $\mathrm{Cu}$ でも認められた 現象である ${ }^{12)}$ 。乙の現象はイオン注入によって発生する 格子欠陷とイオンビーム電流による温度上昇によって引 き起こされる増速拡散であると思われる。 


\section{4. 検 討}

\section{1 摩擦係数と硬さについて}

Crイオンの注入によって軟鋼の摩擦係数は減少し, 一方, 硬さは増加した。この摩擦係数と硬さとの関係 は, 一般には, Bowden の近似式として, 次式のように 示される16)。

$$
\mu=F / P=A_{r} \tau / A_{r} p=\tau / P
$$

ここに, $\mu=$ 摩擦係数, $F=$ 摩擦力, $P=$ 荷重, $A_{r}=$ 真 実接触面積, $\tau=$ 凝着部のせん断強さ, $p=$ 降伏圧力であ る。この式が示すように，摩擦係数は接触している二つ の物質において, 弱い方の材料のせん断強さを金属の降 伏圧力で割ったものとして表現される。なお，本実験に おける弱い方の材料とは注入材として用いた軟鋼と考え られる。この式における降伏圧力は硬さで近似できるか ら, 硬さの増加は摩擦係数の減少を導びくことになる。 一方, せん断強さが小さくなっても, 摩擦係数の減少を おこすことになる。Hartley らは，Sn などを注入した 鉄において 摩擦係数の低下の原因を弱い酸化膜形成に よるせん断強さの減少によるものであると提唱してい

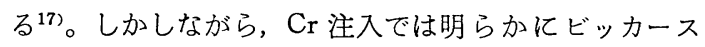
硬さの増加がみられたため, 摩擦係数の減少はせん断強 さの減少によるものではなく, 硬さの増加によって起る と考えられる。

Fig. 6 は $\mathrm{Ni}, \mathrm{Cu}$ 注入材のように摩擦係数を増加させ

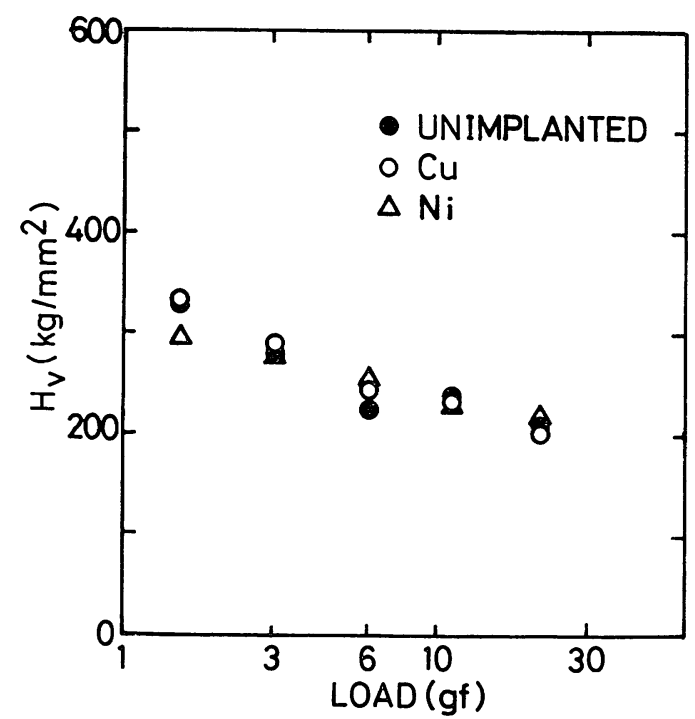

Fig. 6 Vickers hardness as a function of normal load in the case of $\mathrm{Cu}$ and $\mathrm{Ni}$ implantations. Ion implantation was carried out with $10^{17}$ $\mathrm{Cu} / \mathrm{cm}^{2}$ at $150 \mathrm{keV}$ and with $6 \times 10^{16} \mathrm{Ni} / \mathrm{cm}^{2}$ at $100 \mathrm{keV}$.
るむのについての硬さの荷重依存性を示す。 $\mathrm{Cu}, \mathrm{Ni}$ の イオン注入は $1 \times 10^{17} \mathrm{Cu} / \mathrm{cm}^{2}(150 \mathrm{keV}), 6 \times 10^{16} \mathrm{Ni}$ / $\mathrm{cm}^{2}(100 \mathrm{keV})$ で行った。注入材は未注入材とほほ同 じビッカース硬さを示し， $\mathrm{Ni}, \mathrm{Cu}$ イオン注入による硬 さへの効果は認められなかった。また， $\mathrm{Cu}$ を注入した S 25C の硬さを注入層の横方向加ら測定した結果, 明ら かに注入層寄りの硬さは低下しているととがわかった。 したがってでく薄い表面層のやわらかい層は, 表面から の硬さ測定ではバルクの硬さの影響が大きく, 注入層の 硬さ測定は困難であるととを示している。ともかく, 注 入層の摩擦特性には, 注入層の硬さが大きく影響してい ると考えられる。

\section{2 摩擦, 硬さ特性と深さ分布}

$\mathrm{Cr}$ 注入材の摩擦係数は前述したように母材に比べ減 少し, この変化量は注入量の増加とともに大きくなる が，加速電圧依存性についてはあまり明瞭ではない。加 速電圧に対する依存性が弱いという現象は摩擦係数を増 加させる $\mathrm{Cu}$ 注入の場合と大きく異なっている。すなわ ち, $\mathrm{Cu}$ 注入材においては, 摩擦係数の増加は注入量の 增加とともに，また加速電圧の減少とともに大きくなっ ている11)。乙の違いは，注入したイオンの分布に明瞭に 見受けられる。注入した $\mathrm{Cu}$ の分布は，ほぼガウス分布 を示し, また， $\mathrm{Cu}$ は単体の状態で存在していた。しか し， Cr の注入イオン分布は Cr の表面濃化を示し， か つ，酸化した状態で存在していた。したがって， Cr 注 入材に拈ける摩擦係数の減少や硬さの増加は, 表面に濃 化し，酸化した状態の Cr が引き起していると考えられ る。

Cr の表面濃化現象を調べるために，注入イオン分布 の前処理依存性について検討した。前処理した試料はバ フ研磨のみのもの, さらにとの試料を純化した $\mathrm{H}_{2}$ 中で $700 \sim 750^{\circ} \mathrm{C}, 2$ 時間の熱炕理をしたもの，乙れをさらに $5 \% \mathrm{HF}+\mathrm{H}_{2} \mathrm{O}_{2}$ で 10 秒間化学エッチしたあのである。イ オン注入は，乙れらの 3 種の試料を並へ， $150 \mathrm{keV，5 \times}$ $10^{16} \mathrm{Cr} / \mathrm{cm}^{2}$ で行った。注入イオン分布の測定結果を Fig. 7 に示す。試料表面の色が異なっているととから 表面酸化膜の形態がかなり異なっていると考えられた が，てれらの試料の Cr の分布はかなり良く一致してい る。

また, 注入イオン分布の注入量依存性についても調べ た。注入電圧は $150 \mathrm{keV}$ で, 注入量は $1.5 \times 10^{16}, 6 \times$ $10^{16}, 1 \times 10^{17} / \mathrm{cm}^{2}$ の 3 種類である。乙れらの注入イオ ン分布を Fig. 8 に示す。図加ら明らかなように濃化現 象自体は, 注入量に関係なく起っているが, 濃化層に存 在する $\mathrm{Cr}$ の量は高注入量ほど多い。

以上のように, 酸化した $\mathrm{Cr}$ 濃化層形成の度合は, 注 


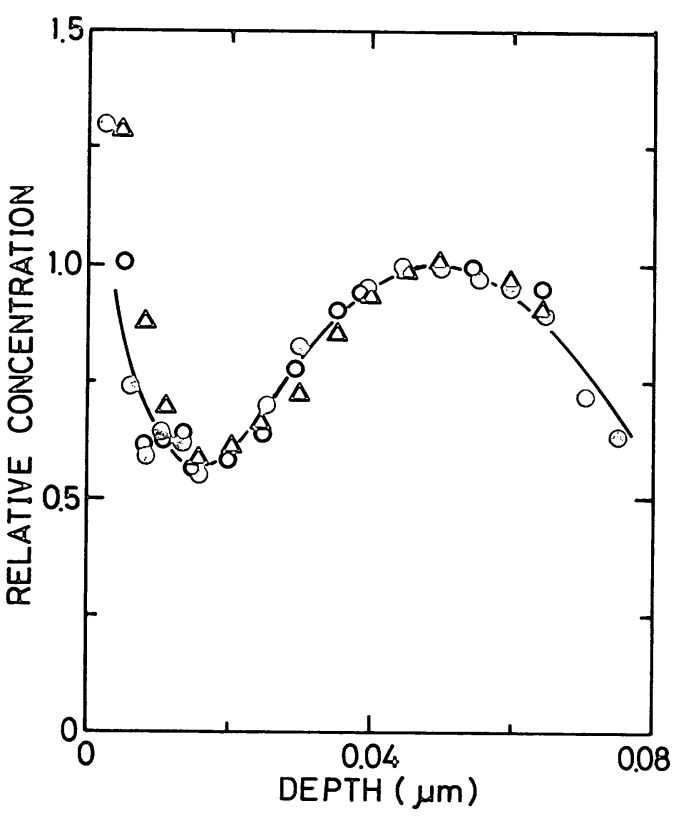

Fig. 7 Concentration profiles of $\mathrm{Cr}$ implanted specimens which were treated variously before implantation.

$\triangle$; mechanical polishing by a buffing whool, A

$O$; annealing the specimen, $A$, in $\mathrm{H}_{2}$ atmosphere, $B$

$O$; chemical etching the specimen, $\mathrm{B}$, in $5 \% \mathrm{HF}+\mathrm{H}_{2} \mathrm{O}_{2}$

入量に依存し, 加速エネルギーの明瞭な依存性はみられ ない。乙の傾向は摩擦係数の減少傾向と対応している。 したがって, 摩擦係数の減少は, 注入表面層 $200 \AA$ 程 度に形成される酸化した Cr の濃化層によって起される と思われる。

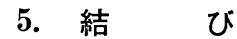

軟鋼板へ Cr 在イオン注入し,その摩擦係数をBowdenLeben 型摩擦試験機で測定し，また，その硬さを超軽荷 重ビッカース硬度計で測定した。Cr のイオン注入は $50,100,150 \mathrm{keV}$ の加速エネルギ, $10^{15} \sim 10^{17} \mathrm{Cr} / \mathrm{cm}^{2}$ の注入量で行った。これらの試料の摩擦特性と硬さ特性 在注入した C r の分布と比較し検討した。これらの結果 定まとめると次のようになる。

（1） Cr の分布は飛程理論で予測される深さ之表面 近傍の二力所にピークをもつ。

（2）表面近傍のピークは注入量に依存し，加速エネ ルギには依存しない。また，濃化層の Cr は酸化してい る。

（3） Cr 注入によって摩擦係数は減少し, その減少

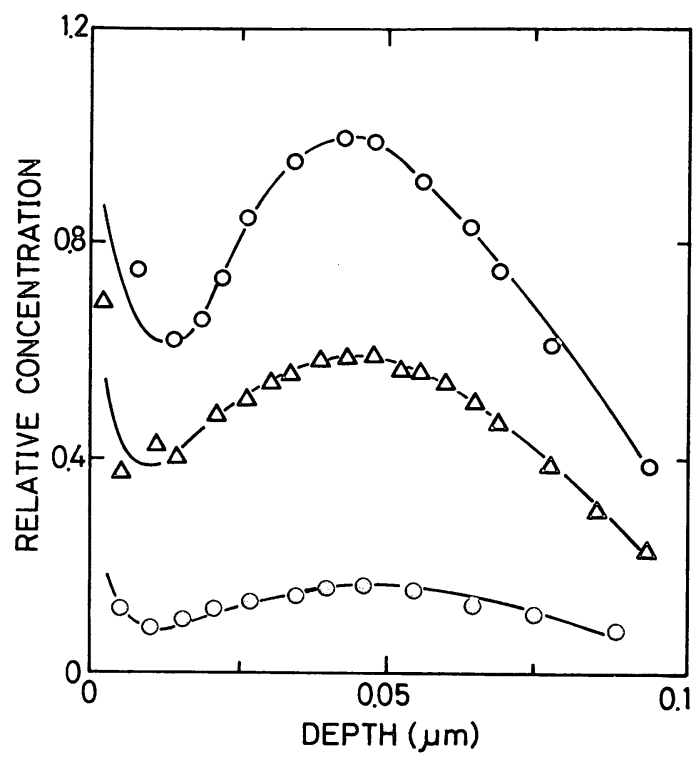

Fig. 8 Concentration profiles of $\mathrm{Cr}$ implanted iron with doses of $1.5 \times 10^{16}(\mathrm{O}), 6 \times 10^{16}(\triangle)$ and $1 \times 10^{17} / \mathrm{cm}^{2}(\mathrm{O})$ at $150 \mathrm{keV}$.

量はの注入量の増加とともに大きくなる。また，乙の性 質は明瞭な加速エネルギー依存性を示さなかった。

（4） Cr 注入によって表面層は硬くなり，硬さの増 加量は注入量の増加ととむに増大する。

以上の結果より C r 注入による摩擦係数の減少や硬さ の増加は表面から $200 \AA$ の間に存在する濃化した Cr の 酸化状態が起していると考えられる。

\section{文献}

1）難波進編著：イオン注入技術（エレクトロニクス 技術全書 8) 工業調査会 (1975).

2) S. T. Picraux, E. P. EerNisse and F. L. Vook: Applications of Ion Beams to Metals, Plenum Press, New York (1973).

3) J. F. Ziegler: New Uses of Ion Accelerators, Plenum Press, New York (1975).

4) J. K. Hirvonen: Ion Implantation, Treatise on Materials Science and Technology, Vol. 18, Academic Press, New York (1980).

5) G. Dearnaley: Materials in Engineering Applications 1 (1978) 28.

6) K. Takahashi, Y. Okabe and M. Iwaki : Nucl. Instrum. \& Methods, 182 (1981) 1009.

7) V. Ashworth, D. Baxter, W. A. Grant and R. P. M. Procter: Corros. Sci. 16 (1976) 775.

8) E. McCafferty, G. K. Hubler and J. K. Hirvonen: Proc. of the 1978 Tri-Service Conf. on Corrosion (eds. M. Levy and J. Brown) Metals and Ceramics Information Center, Ohio (1979) 435. 
9) Y. Okabe, M. Iwaki, K. Takahashi, H. Hayashi, S. Namba and K. Yoshida: Surf. Sci. 86(1979) 257.

10) 岡部芳雄, 岩木正哉, 高橋勝緒: 真空 23 (1980) 438.

11) M. Iwaki, H. Hayashi, A. Kohno and K. Yoshida: Jpn. J. Appl. Phys. 20 (1981) 31.

12) M. Iwaki, S. Namba, K. Yoshida, N. Soda, T. Sato and K. Yukawa: J. Vac. Sci. Technol. 15 (1978) 1089.

13）岩木正哉, 河野彰夫, 曾田範宗 : 潤滑 24 (1979) 353.
14）岩木正哉：アイオニクス 30 (1978) 10.

15) J. Lindhard, M. Scharff and H.F. Schiott : Kgl. Danske Videnskab. Selskab. Mat. Fys. Medd. 33 (1963) 14.

16) F. P. Bowden and D. Tabor: The Friction and Lubrication of Solids (Oxford University Press, Pt II, 1963).

17) N. E. W. Hartley, G. Dearnaley and J. F. Turner: Ion Implantation in Semiconductors and Other Materials, (ed. B. L. Crowder) Plenum Press, New York (1973) 423. 